\title{
Research on the Feasibility and Methods of Increasing Judiciary Credibility with the New Media in China

\author{
Min $\mathrm{CHEN}^{1}$ and Dao-Yong TU²
}

1. School of Humanities \& Foreign Languages, Xi'an University of Technology, Xi'an (710054); Law

School, Wuhan University, Wuhan (430072)

2. Shaanxi Provincial Higher People's Court, Xi'an (710061)

marcy666@163.com*.1725743175@qq.com.

\section{Key words: New media; Public opinion on judicial issues; Response patterns; Judicial credibility}

\begin{abstract}
The $18^{\text {th }}$ National Congress of the Communist Party of China clearly put forward the requirement of fully promoting the rule of law, and set "the steadily enhancement of judicial credibility" as one of the goals of comprehensively building a well-off society in China. Thus it becomes a key issue for the judiciary to accomplish the scientific development on how to increasingly improve the judiciary's judicial credibility. Accordingly, this paper focuses on public opinion on judicial issues and its response patterns in the era of new media, as well as how to realize positive interactions between the new media and judicial activities in such an era.
\end{abstract}

\section{Introduction}

The development of new media put forward new challenges to the judicial credibility in contemporary China. Therefore, it becomes a pressing research issue on how to better safeguard positive interactions between the judiciary and new media and how to make the proper response to the new legal challenges under the new situation.

\section{Impact of the New Media on Judicial Credibility}

Generally speaking, online public opinions through the new media platforms are a double-edged sword to judicial credibility. On the one hand, the new media has played a positive role in promoting judicial credibility; while on the other hand, it also has some negative influences on judicial credibility. And specifically, its influences can be shown in the following aspects:

\section{Influence of New Media on Promoting Judicial Credibility}

First of all, the new media can have a supervisory effect on judicial fairness. The supervision of new media has some profound significance in promoting judicial fairness; and as a result, it becomes a normal state of the judiciary in collecting public opinions on legal issues in China. Through the analysis of public opinions focused on key (legal) issues, the judiciary may discover and respond to the problems as early as possible in order to address the claims of the public, which could further promote realization of the judicial fairness and establishment of it positive image.

Second, the new media can maintain the procedural justice. The following requirements are considered to be the essentials in the justice of criminal procedure, no matter from the perspective of interpreting the notion of natural law, or from that of realizing the procedural justice regarding the democratic rights: participation of the prosecution and the defence in the procedure, right to a fair trial, and judicial openness. In fact, the netizens' voices as the response to the justice reflects their urgent pursuit of judicial fairness, and such pursuit has been expanded from the substantive justice to the procedural justice, while the new media provides such a path in maintaining the justice.

Third, the new media could play a curbing role in reducing judicial corruption. It may expose individual judicial cases "under the sunshine", and make the public to understand more about if the judge's work complies with the law and the procedure. Therefore, the features of new media have 
determined its positive role in the supervision over judicial activities, which can effectively curb judicial corruption.

\section{Negative Influence of New Media on Judicial Credibility}

In the first place, the pan-moralist tendency of new media dashes legal rationality. "The ordinary people are more accustomed to the issue from the moral perspective and request the law to respond to the issue in accordance with such a model." That is to say, most of the public treat the morality and ethics as the standard of judging the right or wrong in a case, and thus further evaluate if the justice can be achieved fairly. As a result, public opinions in the era of new media have ethnical opinions which are mixed with a variety of emotions, rather than with a mode of rational and procedural operation of judicial activities.

Moreover, the non-rational color of new media interferes with judicial independence. The attitude and views towards judicial activities expressed by a citizen through the new media always has the tendency of eroding judicial independence (Zhang 2015). These comments have a strong sense of irrationality and unique personal color. It is just because of such information irrationality and fragmentation of new media that makes the judgment vision of the judiciary on a case different from that of the general public, and then interference with judicial independence.

Furthermore, the new media's "media adjudication" will shake the judiciary's authority. From the perspective of jurisprudence, the "media adjudication" seriously skews the balance of judicial independence and freedom of speech, which is contrary to the spirit of the rule of law. This does not only interfere with the judicial process and hinders normal adjudication of cases, but also seriously undermines the judiciary's authority.

\section{Public Opinion on Judicial Issues and Response Models in the Era of New Media}

\section{Public Opinion on Judicial Issues in the Era of New Media}

Public opinion on judicial issues is becoming a focal point in China's construction of the rule of law. In logics, such opinion can be divided into positive and negative ones, but the main influence on judicial credibility is from the negative one. Accordingly, the negative opinion on judicial issues could be divided into the following types in the light of the causal force theory and standard of tort law: Judicial corruption, miscarriage of justice, and judicial opaque (Jiang and Yang 2014).

\section{Patterns of Response to Public Opinion on Judicial Issues in the Era of New Media}

In general, there are three kinds of response patterns to public opinion on judicial issues from the authority: (1) Escapism. The judiciary adopts an attitude of "three "Nos"”_ neglect, no explanation, and no attitude_— when involving the public opinion on a specific case, under which the opinion of new media has no substantive impact or function on judicial activities. (2) Conformism (Blind compliance). The judiciary follows the "mainstream" public opinion without distinction, which leads the justice bowed to such a view, and finally succumbs to the media and departs from the judicial ethics. (3) "Tai Chi" mode. That is to say, when the public reasonably questions judicial credibility, the judiciary will use the diplomatic terms and become unwilling to give a direct answer to the public, making it difficult to gain the trust of the public on the justice. In the context of rapid change of new media, the judiciary must discard the innate judicial thinking mode, and strengthen judicial credibility through an open and inclusive attitude and positive behaviors.

\section{Recommended Measures for Rebuilding Judicial Credibility in the Context of New Media in China}

Nowadays, against the background of rapid development of new media, China faces completely new challenges to judicial credibility on how to coordinate the relationship between judicial independence and freedom of expression and offset the discordant state between judicial justice and 
public opinion on judicial issues. However, such challenges are also an opportunity, as the rule-of-law spirit and notion can be disseminated after spread of judicial cases through the new media, which can contribute to the promotion of judicial credibility.

\section{Applying the Scientific Nature of Response Principles in Safeguarding Judicial Credibility}

In our view, the judiciary should adhere to the following principles when responding to the public opinion on judicial issues in the era of new media: (1) Principle of timeliness. As for the facts that it grasped, the judiciary should make public the truth to the public in a timely manner, and announce relevant information through the new media, and deliver the transparency and impartiality of the judiciary (in handling cases) to the public, in order to eliminate concerns of the public, and reduce possible spread of false information. (2) Principle of rationality. Judicial rationality is the prerequisite of judicial fairness, while the former should take the public opinion to the direction of rationality that complies with the rule of law. The openness of judicial activities should be applied in those cases that do not involve the state secret and personal privacy, through which the judiciary can make use of the judicial rationality to settle the crisis of public opinion and enhance judicial credibility (Han 2016). (3) Principle of positive interactions. The judiciary should firstly change their notions, and then enrich and develop the methods of communication with public opinion on judicial issues, establish an internal team in response to the opinion on judicial issues, and improve the reporting mechanism for monitoring the management of public opinion, and eventually form a rapid verification mechanism and corpus of judicial cases. At last, the judiciary should create a positive, effective and interactive vertical system in responding to the public opinion.

\section{Improving Judicial Credibility with the Effectiveness of the Response System}

In the context of new media revolution, it is also meaningful for the judiciary to consider how to positively, rationally and normatively respond to the public opinion on judicial issues in addition to use rational arguments by different groups such as the experts and general public in promoting judicial credibility. Specifically speaking, the following measures can be considered by the judiciary. First of all, it should improve the ability to respond to the public opinion on judicial issues. In order to accomplish this goal; the judiciary should establish an effective mechanism in this regard. In particular, the judiciary should establish an internal response group responsible for studying the public opinion on judicial issues and putting forward the countermeasures, and then release the information through new media by its publicity department. Secondly, it should create an effective public opinion control system. The judiciary should form a network with professional monitoring, collecting the information on public opinion, and make use of a team of online commentators to guide the online opinions. Thirdly, it should create a speedy verification mechanism, and apply differentiate approaches such as the cold treatment, self-examination and rights protection through legal channels in handling public opinion on judicial issues according to the degree of influences of the opinion and truth of the issue. Finally, the judiciary should establish a routine monthly reporting system of public opinion, report such opinion on judicial issues with higher impact to the provincial judicial authorities by steps, and then the publicity department shall form a monthly newsletter and report it to the person in charge of the judiciary at the provincial level.

\section{Improving Judicial Credibility through the Diversified Response Measures}

There are various approaches in responding to the public opinion on the judiciary and judicial activities. For example, firstly, live broadcast of the trial through the blog. Such live broadcast will achieve the symmetric transmission of relevant information on the operation of the justice between general public and the judiciary, which contribute to help the public have an in-depth understanding of case facts, and avoid their misunderstanding on the judgment because of the differences between judicial standards and public cognition. Moreover, live broadcast of the trial through the blog could obligate the judge to apply the judicial power carefully, allowing their behaviors under the whole-process supervision of the public, which can achieve the judicial justice in a more precise and visible way (Xiang and Huangpu 2014). Secondly, publication of the judgments on the new 
media platform. This will help the public understand the whole process of the litigation, and convey the basic information on the operation of justice to the public, making the decision more lawful and justified, which can improve the credibility of the judiciary invisibly. Thirdly, development of the spokesman system assisted by the Wechat video conversation technology. At present, the judiciaries at various levels have established a spokesman system in China except those at the grassroots level. Therefore it is particularly important to improve the spokesman system supported by the new media.

\section{Summary}

Along with the acceleration of judicial reform and improvement in the mechanism of responding to the public opinion on judicial issues in China, we argue that the judiciary should respect more on public opinion in the context of new media and accept the supervision of public opinion more voluntarily. Consequently, a positive interaction between the justice and public opinion can be formed in China which can satisfy public pursuit of the justice and fairness and thus improve public trust in the justice.

\section{Acknowledgement}

This research was financially supported by the National Social Science Fund West China Project: Breaking "the Stereotypes": An Analysis and Prevention of Criminal Misjudged Cases from the Perspective of Evidentiary Adjudication (2016) Project Grant No. [16XFX010]

\section{References:}

[1] Hang, Wei (2015). "Research on Relevant Issues Regarding the Credibility of Justice_C Challenges in Putting into Effect the Credibility of Justice and Solutions in the Era of New Media". Legality Vision (Fazhi Bolan), 3(I):180-182. [Project Grant No. 13JK0085].

[2] Jiang, Huiling, and Yang Yi (2014). "Multiple Comparison of the Relationship of Judicial Openness with the New Media”. The People's Judicature: Application (Renmin Sifa: Yingyong) 19:4-9.

[3] Han, Wei (2016). "Emerge, Impact and Governance of Case-related Online Public Opinions". In Zhang Chuan (ed.), Social Public Sentiment: Core Issues and Social Governance Practice (Shehui Yuqing Hexin Yiti yu Zhili Shijian). Beijing: Social Sciences Academic Press (China).

[4] Xiang, Yong, and Huangpu Xiaotao (2012). "Content Production of the Pan-media Revolution and the New Mass Media Cultural Innovation”. Journal of Beijing Union University (Humanities and Social Science Edition) (Beijing Lianhe Daxue Xuebao [Renwen Shehui Kexueban]) 4:76-81. 